\title{
Situation of the Csángó Dialect of Moldavia in Romania
}

\section{Siarl Ferdinand}

\begin{abstract}
The following paper analyses the situation of the Csángó dialect spoken in the Romanian region of Moldavia. After a review of the global phenomenon of language death, its causes, and some resources to evaluate language vitality, the study focuses on the Csángó community and its Hungarian dialect. A short description of some fundamental facts about the group, such as ethnicity, religious affiliation, and linguistic background sets the base for an in-depth study of the language situation. In order to achieve that goal, the language was scrutinized according to the nine factors proposed by the UNESCO's Language Vitality and Endangerment (LVE) framework. The results confirm previous research in the field and show that Csángó is experiencing a decisive and most difficult phase in its history. It is expected, however, that this paper can contribute to create a successful planning to preserve not only Csángó but many other languages and dialects in similar situations.
\end{abstract}

Keywords: Csángó, language shift, Romania, Szeklers, Roman Catholics in Romania, Bacău

Biography: Siarl Ferdinand is a Ph.D. candidate in Bilingual Studies at University of Wales Trinity Saint David. He is currently teaching at the English Language Institute of the American University in Blagoevgrad, Bulgaria. His main research interests include topics related to minority languages and cultures from Europe and Central Asia such as language revitalization, language maintenance, and language death, among others.

\section{Language Death and its Causes}

Language death has been defined as "the loss of a language due to gradual shift to the dominant language in language contact situations" (Campbell 1994, 1961). A language could be considered dead when it has ceased its function as a communication tool, which means that nobody speaks it any longer because regular communication is carried out in another language (Crystal 2000: 1). Often, knowing the reasons why a language is dying may help it to get revived, thus as regards to language revival, the first step to be taken is to determine the causes of language death. As happens with people, there are three main reasons that may affect the vitality and health of languages, namely evolutive, physical, and psychological causes.

The evolutive causes would include all the reasons that provoke relatively small changes in a language causing the slow death of the original language while transforming itself into another language of the language family. Some of these changes may be intentional, due to national or regional language planning, such as standardization, while some others are caused by 
Ferdinand, Siarl. "Situation of the Csángó Dialect of Moldavia in Romania." Hungarian Cultural Studies. e-Journal of the American Hungarian Educators Association, Volume 9 (2016): http://ahea.pitt.edu DOI:

other factors such as language change through time, pidginization, and creolization. Some notable examples of this kind of causes of language death include Latin and Sanskrit. Both languages are considered to be dead although what they actually experienced is a transformation which provoked the birth of large language families including French, Italian, Romanian and others in the case of Latin, and Hindi-Urdu, Punjabi, and Bengali among others in the case of Sanskrit.

A second group includes all the reasons for language death due to physical threat of the individual speakers and/or their communities. These threats can be man-made, such as wars, genocides, or massive immigration, or natural such as earthquakes, floods, and epidemics. Wars and massacres, for example, provoked the death of ancient Hungarian in Magna Hungaria, today's Bashkiria, one of the republics of the Russian Federation. Apparently, as Friar Julian reported, Hungarian was widely spoken there until the 1230s. However, the Mongol invasion or Tatárjárás suffered by eastern and central Europe in the late 1230s and early 1240s wiped out, among others, most of the local Magyar population in Russia. Apparently, the survivors abandoned their language and shifted to Russian and Qipchaq. By comparison, the so-called Minoic language in Crete, the largest of the Greek islands, is a victim of natural physical causes for language death since it suffered general decline and death after the destruction of their centers due to the Thera eruption in the second millennium BCE.

In general, the factors and sub-factors mentioned above affect the usefulness of the language. The last group is a combination of all the reasons for language decline which are not caused by the passing of time or by any direct physical threat. These reasons attack the dignity of the language and often have a social background caused by ideological or practical reasons. Sometimes, language abandonment is apparently voluntary on the part of its speakers, although it may also be the final reaction to episodes of repression or some physical causes. Overt and covert pressures without threat of the life of its speakers can also cause the dismissal of a language by a community favoring a more prestigious variety of it (another dialect) or even other languages. Most Native Americans, who are currently English native and often monolingual speakers, are a living example to illustrate this case. After the long lasting language imposition that they suffered, they continue living in English and teaching English to their children, since it is an internationally prestigious language which can open uncountable opportunities to its speakers (see Table 1).

\begin{tabular}{|c|c|c|}
\hline 0. Evolutive causes & 1. Physical causes & 2. Social Causes \\
\hline 0.1 Language change & 1.1 Man-made physical causes & \multirow[t]{2}{*}{2.1 Overt repression } \\
\hline $\begin{array}{l}0.2 \text { Pidginization and } \\
\text { creolization }\end{array}$ & 1.1.1 Genocide, massacres & \\
\hline \multirow{3}{*}{$\begin{array}{l}\text { 0.3 Standardization } \\
\text { (affecting dialects) }\end{array}$} & 1.1.2 War & 2.2 Covert pressure \\
\hline & 1.1.3 Deportation & 2.2.1 Socioeconomic reasons \\
\hline & $\begin{array}{l}\text { 1.1.4 Relocation } \\
\text { - } \\
\text { - } 1.1 .4 .1 \text { Voluntary } \\
\text { - } \\
\text { 1.1.4.3 Massive immigration }\end{array}$ & 2.2.2 Sociocultural reasons \\
\hline
\end{tabular}


Ferdinand, Siarl. "Situation of the Csángó Dialect of Moldavia in Romania." Hungarian Cultural Studies. e-Journal of the American Hungarian Educators Association, Volume 9 (2016): http://ahea.pitt.edu DOI:

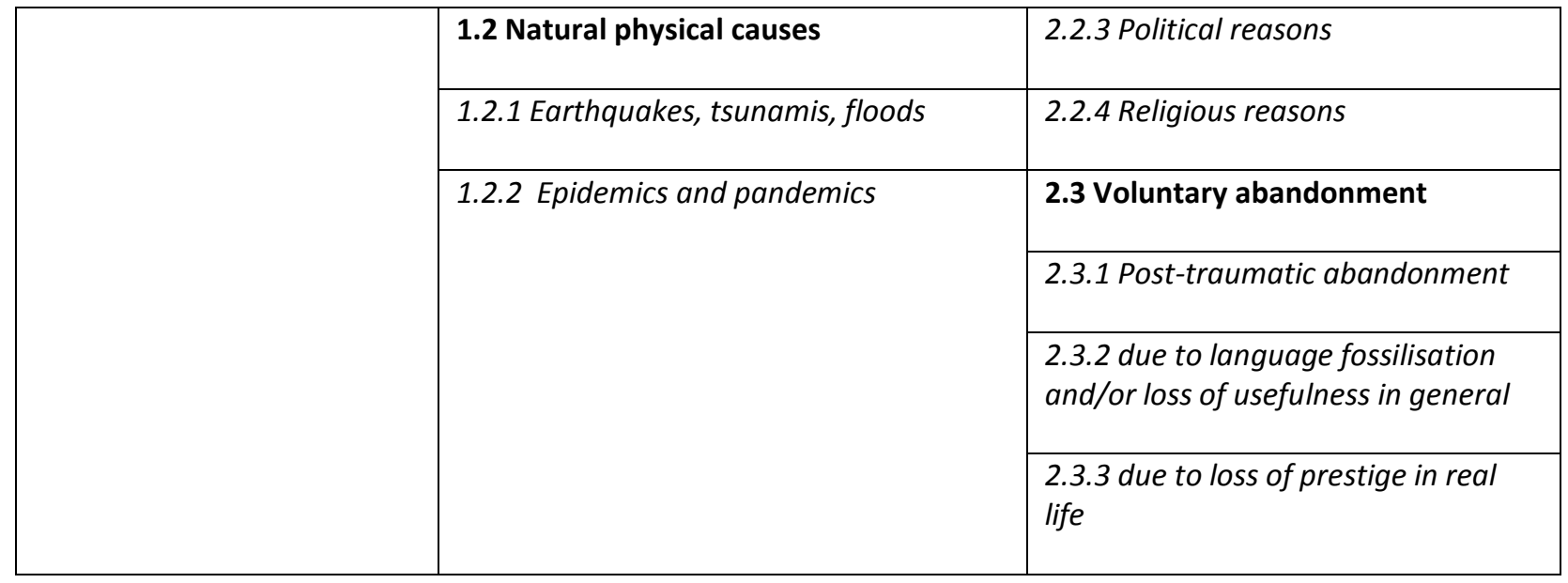

Table 1. Causes of language death

Although language death has always been part of history, it had never been so pronounced. Nowadays, between fifty and ninety percent of the living languages are affected by a massive wave of extinction (Harrison 2007: 7). The fact has provoked an imperative for language documentation, new policy initiatives, and new materials to enhance the vitality of the affected languages or dialects (UNESCO 2003: 1). In order to develop effective language policies and strategies, a number of experts have created different tools to assess language vitality such as Fishman's (1991) Graded Intergenerational Disruption Scale (GIDS) or UNESCO's (2003) Language Vitality and Endangerment (LVE). This paper analyses the situation of the Csángó-Hungarian dialect spoken in the Romanian region of Moldavia using UNESCO's LVE, since other works, particularly János Heltai (2012), have already described it according to GIDS.

UNESCO's LVE, which evaluates the level of vitality of a given language or dialect, is based on nine major factors: 1) "Intergenerational Language Transmission," or whether the language is passed on from parents to children; 2) Absolute number of speakers; 3) Proportion of speakers within the total population of the ethnic group (as for example Hungarian speakers among the Csángó ethnic population without considering Romanians, Szeklers, Gypsies, and others who inhabit the same region); 4) Shifts in domains of language use or, in other words, the situations in which the language is employed; 5) Response to new domains and media such as the visibility of the language on the Internet, television, newspapers, etc.; 6) Availability of materials for language education and literacy; 7) Governmental and institutional language attitudes and policies, including official status and public use; 8) Community members' attitudes towards their own language, and 9) Type and quality of documentation, such as the kinds of material written or spoken in the language, which may include grammar books, stories, text books, TV or radio programs, websites, etc. All these factors should be used in connection. Every factor, except number 2, is graded from 5 (safest) to 0 (extinct or riskiest situation).

Factor 1 or "Intergenerational Language Transmission" is probably the most commonly used factor in evaluating the vitality of a language, since no language or dialect can possibly survive as a tool for daily communication if it is not passed to the younger generations. Languages are alive as long as there are people who speak them. Nevertheless, the number of speakers itself does not guarantee its survival. In fact, a language may be alive and have thousands or even hundreds of thousands of speakers and yet be endangered. Occitan (also called 
Ferdinand, Siarl. "Situation of the Csángó Dialect of Moldavia in Romania." Hungarian Cultural Studies. e-Journal of the American Hungarian Educators Association, Volume 9 (2016): http://ahea.pitt.edu DOI:

Provençal), which used to be the most prestigious Romance language during the Middle Ages, is still spoken by more than one million people in France; however, its state is far from being safe. Some decades ago, most Occitan-speakers quit transmitting the language to their children; thus, nowadays, most speakers belong to the older generations (grandparents and great grandparents). If there is no reactivation in transmission to children either from grandparents to grandchildren, or at school, Occitan will find itself in a highly desperate state with the passing away of the older generations, in probably less than thirty years. On the other hand, some smaller languages like Icelandic (250,000 speakers), Faroese (50,000 speakers) or Luxembourgish (300,000 speakers) seem to have a safer future since they are transmitted to the younger generations both in the home and at school. Those languages, therefore, do not only depend on the older individuals of the community.

Factor 2 denotes the absolute number of speakers. A language with few speakers is more exposed to decline and death in case of physical and social threats since the loss of a few speakers may represent a high percentage for it. Nowadays, it would be difficult for a catastrophe or war to kill the English language. However it is very likely to assume that a language spoken by a few individuals in only one village may disappear if a tsunami or an earthquake destroys the area.

Factor 3. The proportion of speakers within the total population also plays an important role in language vitality. This factor evidently applies to languages spoken in countries or regions where other languages and dialects are also spoken. In most cases, there is only one prestigious language or dialect (i.e., the majority language) in the area that is spoken and/or understood by most of its inhabitants while the rest of the languages are considered "minority languages." The majority language is generally used as an interethnic or intertribal language (also called the lingua franca) which is also employed in most domains such as education, the media, etc. This situation often impels individuals to abandon their native languages and to shift to the prestigious one, thus the only possibility in which the minority language can be employed is with members of the group who still preserve it. Therefore, the higher the proportion of speakers is in a community, the higher the probabilities of using the minority language is. In Romania, there are several languages and dialects spoken such as Romanian, Hungarian (including Csángó), German, Romany, and others. In most regions, Romanian is both the majority and the most prestigious language which is used at school, in the shops, by government officials, etc. Therefore the only possibility to use the rest of the languages would be with some members of the group, since it would be totally unrealistic to employ them as the only communication tool.

Factor 4. The domains or situations, such as education, school services, and the media, in which the language is used affects whether it is transmitted to the next generation or is discarded. Generally, if the language is useful, parents tend to pass it to their children, since it will be a tool to use at school, to have a career, to understand religious services, TV, internet, and so on. However, if it is used in only a handful of situations which can be also carried out through the medium of a majority language, most probably parents will consider transmitting the majority language. For example, most Hungarians, Jews, and Italians in the USA decide to teach English instead of Hungarian, Yiddish, or Italian to their children since English is the only language which can help them to succeed at school and in the work place.

Factor 5 is intended to establish the degree of response to new domains and media by the community. Usually, when a community does not get adapted to modernity, there is a high risk of increasing the perception of its language as something from the past and thus useless. 
Ferdinand, Siarl. "Situation of the Csángó Dialect of Moldavia in Romania.” Hungarian Cultural Studies. e-Journal of the American Hungarian Educators Association, Volume 9 (2016): http://ahea.pitt.edu DOI:

Although it belongs to the country's cultural heritage, nobody decides to study Latin in Romania nowadays in order to be more informed about what happens in the world, to listen to the latest music hits, or to watch the most popular TV shows and movies. That language is considered a relic of the past while Romanian, which is totally adapted to modernity, is learnt by individuals from all ethnic and cultural backgrounds in the country.

Factor 6. Since education in the language is essential for its preservation, the availability of materials on all topics is generally necessary. Therefore, it is not only important to have good dictionaries or grammar books in Csángó, but also materials to teach subjects like geography, mathematics, and physics. Without those materials, students and teachers would be forced to use other languages or dialects like Romanian or standard Hungarian to discuss class topics. Literacy is directly linked to social and economic development (UNESCO 2003: 12).

Factor 7. Governments and institutions have explicit policies that often determine the social position of languages and influence people's attitudes towards them. In Romania, the only official language, compulsory to all its inhabitants independently of their ethnicity and linguistic background, is Romanian. The rest of the languages, like Hungarian, Romany, or German, do not enjoy the same rights and privileges that the Romanian language and the Romanian speaking population do.

Factor 8. The perception of the community members towards their language has a deep impact on its intergenerational transmission and on the domains in which it is used by the speakers. If Csángó-Hungarians consider that their dialect is useless, ugly, or associated with any other negative characteristic, they will tend to transmit another language (Romanian) or dialect (Standard Hungarian) to their children. If, on the other hand, they appreciate it as a cultural symbol or as a useful language to be employed in commerce, education, the church, etc., they will decide to continue speaking it at home with their children.

Factor 9. The type and quality of existing language materials must be identified in order to assess the urgency of the need for documenting a language. Those materials may include all kind of books, magazines, articles, and websites written in the language (Csángó in this case). Ideally, there would be also recordings like radio recordings, MP3 files, TV programs, and videos. This kind of information enables linguists to design useful projects and strategies together with members of the language community.

\begin{tabular}{|l|l|l|}
\hline Factor & & \multicolumn{1}{|c|}{ Scale } \\
\hline 1 & Intergenerational language transmission & From 5 (safe) to 0 (extinct) \\
\hline 2 & Absolute number of speakers & Real number \\
\hline 3 & Proportion of speakers within the total population & From 5 (safe) to 0 (extinct) \\
\hline 4 & Shifts in domains of language use & From 5 (universal use) to 0 (extinct) \\
\hline 5 & Response to new domains and media & From 5 (dynamic) to 0 (inactive) \\
\hline 6 & $\begin{array}{l}\text { Availability of materials for language education and } \\
\text { literacy }\end{array}$ & From 5 to 0 (no orthography available) \\
\hline 7 & Governmental and Institutional Language Attitudes and & From 5 (equal support) to 0 (prohibition) \\
\hline
\end{tabular}


Ferdinand, Siarl. "Situation of the Csángó Dialect of Moldavia in Romania.” Hungarian Cultural Studies. e-Journal of the American Hungarian Educators Association, Volume 9 (2016): http://ahea.pitt.edu DOI:

\begin{tabular}{|l|l|l|}
\hline & Policies, Including Official Status and Use & \\
\hline 8 & $\begin{array}{l}\text { Community Members' Attitudes towards Their Own } \\
\text { Language }\end{array}$ & $\begin{array}{l}\text { From 5 (all members value) to 0 (no one } \\
\text { cares) }\end{array}$ \\
\hline 9 & Type and Quality of Documentation & From 5 (superlative) to 0 (undocumented) \\
\hline
\end{tabular}

Table 2. LVE Factors (UNESCO 2003)

\section{The Csángó Community}

The Csángós, Csángók in Hungarian and Ceangăii in Romanian, are a Hungarianspeaking ethnic, linguistic, and religious group of Romania. Traditionally, the community itself had little consciousness of itself as a group, thus the name Csángó was given to them by their neighbors to distinguish them from other Hungarian-speaking groups such as the Szeklers (Székely) living in Transylvania and Moldavia (Sándor 2005: 169). Nowadays, most Csángós live in about ninety small villages and towns in Bacău (Bákó) County ${ }^{1}$ in the Romanian region of Moldavia, near the eastern side of the slopes of the Carpathians, although historical records and local toponymy seem to indicate that in the past they were spread out on a much larger territory (Baker 1997: 659). The number of Csángós living in Romania is not clear. For centuries their identity was based on two main factors, their Roman Catholic faith and their Hungarian dialect. Therefore, nowadays their number ranges from 260,000 individuals (based on the Catholic population in the area), to 70,000 (based on the capacity to speak the Csángó dialect), or even to only a few thousand (based on the fact that only 1,536 persons declared themselves Csángós in the most recent Romanian Census) (Institutul Național de Statistică 2012).

Despite the fact that the group live in Europe - one of the continents where remoteness is less common - the Csángós are one of the most enigmatic communities regarding their origins, which has produced a number of contradictory theories to explain its existence. Although all these theories are to some degree initially based on scientific investigations and research, it cannot be denied that they are often strongly influenced by political views of two rival states, Hungary and Romania (Filip 2011). The two main nationalist currents are outlined in the "continuity theories," formerly backed by Hungarian anthropologists, and in what could be called "Hungarization theories," proposed and backed by Romanians. Although the most extreme proposals of both theories have been discarded by modern scholars, they remain popular in their respective countries. The "continuity theory" proposes an arrival of the proto-Csángó before the arrival of the Magyars (Hungarians) to central Europe in the ninth century, which would make them a sort of pioneers among the Magyar tribes who, at that time, inhabited the plains between the Dnieper and Dniester rivers in central Ukraine. A thesis related to the continuity theory, or rather a variant of it, is the one proposed by Gyula László (1986) in which he suggests a conquest of Pannonia in two stages, a first one during the seventh century CE, and a second one during the ninth century CE. The remains of the first Hungarian wave were the

${ }^{1}$ In the current paper, geographical names of villages, towns, cities and regions of Romania where Hungarian is spoken are given in its official Romanian form followed between brackets by the often original Hungarian version. 
Ferdinand, Siarl. "Situation of the Csángó Dialect of Moldavia in Romania." Hungarian Cultural Studies. e-Journal of the American Hungarian Educators Association, Volume 9 (2016): http://ahea.pitt.edu DOI:

Szeklers and the Csángós, while those arriving in the second wave, the "Árpád's people," were the Magyars, the main Hungarian group (László 1986: 6, 16, 17, 24).

The opposite theory was mainly developed by Petru Râmneanţu (1944) and revised lately by Dimitru Mărtinaş (1985) who declared that the Csángós were originally Romanians (from Transylvania) who converted to Catholicism and adopted Hungarian as their language (Râmneanţu 1944: 55-57). This theory is still the most popular in Romania and is promoted by different circles including some organizations within the Catholic Church, the Romanian government, and some intellectuals (Asociaţia Romano-Catolicilor "Dumitru Mărtinaş" 2014; Năstase 2002: 3; Filip 2011). Despite its popularity in Romania, this theory has not gained the recognition of international academia since there is historical evidence in documents, place names, and proper names which attests to a Hungarian presence before the Romanian influx in certain strategic areas of Moldavia near the Carpathian passes (Stir 2011; Tánczos 1997: 371).

There are, however, some alternatives to these maximalist theories. For centuries, the Csángós were regarded as descendants of the Cumans (Western Qipchaq). In the twentieth century, Bernát Munkácsy (1902) and Endre Veress (1989) insisted on a possible Cumanian origin for the community based, among other variables, on linguistic evidence (Kálmán 2002: 10). Other authors have proposed some similar variants to these hypotheses, among them Sándor Szilágyi (1979), who theorized a Magyar-Khazar origin. These theses have attracted the attention of both Hungarian and Romanian scholars such as Gheorghe I. Brătianu (1943) and Nicolae Iorga (1988) who saw very plausible a Turkic (Cuman or Pecheneg) origin of the Csángós (Baker 1997: 662). Another set of theories links the Csángós with other Hungarian-speaking groups who may have arrived to the area by the fourteenth century, although they do not agree whether they are Magyars or Szeklers (Sándor 2005: 164; Baker 1997: 664).

Despite these often contradictory hypotheses, Csángós have their own point of view about themselves. On the one hand, they see themselves as Hungarians, as the lyrics of their anthem show, which begins with the verses "Csángó magyar, csángó Magyar/Mivé lettél csángó magyar?" ['Csángó Hungarian, Csángó Hungarian/What have you become, Csángó Hungarian?']. However, it does not mean that they have any generalized secessionist, autonomist, or any other ethno-political feeling. Their identity feelings range from a minority who consider themselves ethnically and nationally Hungarian, to those who think that the group is composed by Catholic Romanians with Hungarian origin, to those who simply consider themselves Moldavian Catholics (Tánczos 2002: 136-137). This last point of view is one of the most common within the community and it is similar to that of Crimean Tatars, who used to see themselves much more as Muslims of Crimea than as a Turkic speaking ethnicity, or the Amish community in the United States, who are defined by their religious filiation rather than by their German ancestry and dialect (Shetreet 2007: 105; Uehling 2004: 202).

\section{History of the Csángó Dialect}

Although the Csángós are originally a Hungarian-speaking group, it must not be concluded that their way of speaking Hungarian follows the same standards as the speakers from Budapest, Transylvania, and Hungarian-speaking regions of Slovakia, Serbia, Croatia, Austria, or Slovenia. Despite the fact that one of the earliest records about the use of Hungarian by the Moldavian Csángós dates from 1760s, the systematic study of Hungarian dialectology only began in the 1870s. One of the first papers to scientifically describe the Csángó dialect was published in 1874 by Gábor Szarvas. He described some similarities between the Szekler (or Székely) and the Csángó Hungarian dialects, but he also pointed out some peculiarities of the 
Ferdinand, Siarl. "Situation of the Csángó Dialect of Moldavia in Romania." Hungarian Cultural Studies. e-Journal of the American Hungarian Educators Association, Volume 9 (2016): http://ahea.pitt.edu DOI:

latter. Apparently those differences were not small, since Antal Horger (1934) declared that, due to those particularities and to the high number of Romanian terms, Csángó is almost unintelligible for the rest of the Hungarian speaking groups (Benő 2012: 13, 14). Horger's (1934) opinions can be considered an exaggeration, since the dialect does not prevent communication between Csángó and the rest of the Hungarian-speaking community, but, nevertheless, they do point out that the archaic Csángó dialect is a very peculiar variant of Hungarian due to the isolation of the group. The Moldavian Csángós did not take part either in the Hungarian Revival in the nineteenth century or in the reform of the language, and therefore they were not influenced by the cultural revolutions and changes emanating from centers such as Budapest, Szeged, Debrecen, or by the then Hungarian-speaking cities of Cluj-Napoca (Koloszvár) and Brașov (Brassó), both in Transylvania. In fact, education in the area had always been through the medium of Romanian, except for the short period between 1947 and 1955 (Kiss 2012: 115).

In the region of Moldavia, the adjectives "Csángó" and "[Roman] Catholic" are almost interchangeable, since the Romanian population follows the Orthodox Church and the rest of the Hungarians and Szeklers mainly belong to Reformed churches (Andreescu 2004: 65). The history of the Csángós is strongly linked to that of the Roman Catholic Church, and, in fact, the earliest references to the Hungarian-speaking communities in Moldavia are only found in the Church registers of the area (Bitay 1926: 5). Religion has traditionally played a key role within the Csángó communities since, contrary to what happened in other Hungarian-speaking areas in the Kingdom of Hungary, the Moldavian Csángós had neither a state nor an educated class. Therefore, the Catholic Church, in the person of the priests, was expected to provide the group with guidance with regard to the most important matters of life. For the group, the rituals such as attending Mass on Sunday, confession and communion were much more than religious obligations; they were acts of identity reaffirmation in front of their Romanian-speaking Orthodox neighbors (Kálmán 2002: 31).

Some of the first linguistic details about the Csángó population in Moldavia can be extracted from the so-called Baldinus's census (1646-1647), where it can be deduced that the majority of the local families in the region had Hungarian origins (Kiss 2012: 113). The Hungarian scientific attention, however, did not begin until the first part of the nineteenth century. Since those first details and first research works the percentage of Csángó-Hungarian speakers has decreased dramatically. The cause for this decline must be identified as a set of reasons through, at least, the last four centuries. One of the first causes of language change among the community has to do with relocation of either the Csángós themselves, or of other ethnicities to the Csángó areas of Moldavia. Since, as mentioned previously, there are several theories about the origin of the Csángós, the relocation or immigration mentioned could be either by Csángós from possibly Transylvania (Sub-factors 1.1.4.1 and/or 1.1.4.2, see Table 1) or by Romanian-speaking groups originally from other parts of Moldavia and Wallachia (Sub-factor 1.1.4.3). This situation was the first step for Hungarian-Romanian bilingualism amongst the Moldavian Catholics while Moldavian Orthodox continued to be Romanian monolingual speakers, since they constituted the majority of the population and had no need to learn the Hungarian language (Kiss 2012: 114).

Despite these circumstances, the Hungarian-Csángós succeeded over the centuries in maintaining their status as free tenants guaranteed by the King of Hungary, who was the most powerful ruler of the area. Moreover, some Csángós occupied important positions within the Moldavian Voivodship. These privileges helped the Hungarian community to maintain their language, religion, and culture (Tánczos 2002: 119-120). However, the situation radically 
Ferdinand, Siarl. "Situation of the Csángó Dialect of Moldavia in Romania." Hungarian Cultural Studies. e-Journal of the American Hungarian Educators Association, Volume 9 (2016): http://ahea.pitt.edu DOI:

changed in 1526. The royal troops of the King of Hungary were defeated by Suleiman in the battle of Mohács, opening the way for the Ottoman Empire to invade a huge part of the Kingdom of Hungary and devastating Moldavia (Kálmán 2002: 15). The Magyar king, the rest of the royal institutions, and the special status of the Hungarians in Moldavia became a remembrance of the past and the Csángós became an often despised minority mainly due to their religious affiliation. The lack of a Kingdom, the lack of a local intelligentsia, and the relative isolation of the community from other similar groups, such as other Hungarians or other Catholics, provoked a total cultural dependence on the Romanian-speaking world, a factor that is still valid during the twenty-first century. This also implied strong and continuous covert pressure (Factor 2.2) in many fields, such as the socioeconomic one (Sub-factor 2.2.1), the sociocultural one (Sub-factor 2.2.2) and evidently, the political one (Sub-factor 2.2.3). With most main domains lost, for most Csángós, Hungarian was reduced to the private language of the home and of the Church. This later domain was considered the most important one for the community since their main feature or characteristic was not the language but their Roman Catholic religion in a RomanianOrthodox region. Therefore, as long as Hungarian was the language of the Catholic Church, its survival was assured.

However, something changed in the seventeenth century when the Roman Catholic Pope declared Moldavia a missionary region and his plan to convert the Romanian-speaking population included the assimilation of the Hungarian Csángós. The Vatican ordered Polish and Italian priests who did not speak Hungarian to the area in order to make of the Catholic Church a Romanian-speaking church that would be more attractive to the Romanian majority. With these important changes, Hungarian, therefore, lost the Church, the most prestigious domain in the Csángó society (Sub-factor 2.2.4; Kiss 2012: 114-115). Covert pressure from the majority was not the only problem that the language suffered in Moldavia. Very often the Csángós and their culture were the object of governmental proscription or overt repression (Factor 2.1) as is illustrated by the fact that although there have been Hungarian schools in Transylvania and Bukovina for centuries, and other minorities such as Muslims were given the right to learn Turkish, Moldavian Csángós were denied even the possibility to learn their dialect since the government forbade the use of the language even to teach Catechism. Bucharest sent Romanianspeaking Orthodox teachers to the Csángó villages with the objective of assimilating the community and punishing the use of Hungarian at school (Vincze 2002: 54, 56; Brassai 1913: 11-12). Assimilation also included the government decreeing the forced Romanization of the Hungarian names, that were often translated, or when no Romanian equivalent was available, written according to the Romanian spelling (Vincze 2002: 56). The history of the CsángóHungarian dialect must be seen as the gradual death of a language in mainly four different periods:

- Relocation provoking a minorization of the Hungarian language which forced a friendly bilingualism in order to communicate with the main linguistic group (Sub-factor 1.1.4).

- Covert pressure in all fields, economic, social, political, and religious (Factor 2.2)

- Overt repression by both the Romanian Government and by the Catholic Church by prohibiting masses in Csángó, the teaching in Hungarian, and even Romanizing names (Factor 2.1).

- After neglecting any trace of usefulness and of dignity to the language, the fourth period is characterized by a voluntary abandonment of the language (Factor 2.3). 
Ferdinand, Siarl. "Situation of the Csángó Dialect of Moldavia in Romania." Hungarian Cultural Studies. e-Journal of the American Hungarian Educators Association, Volume 9 (2016): http://ahea.pitt.edu DOI:

\section{The Current Situation of the Csángó Dialect according to UNESCO's LVE}

Factor 1: Intergenerational language transmission. According to Vilmos Tánczos (2012: 240-278), most Csángó-speakers are older than forty-five, with an overwhelming majority of speakers also over sixty. In settlements like Traian (Újfalu), Băluşesti (Balusest), and Faraoani (Forrófalva), just to mention a few, all the speakers belong to the oldest generations. In other villages where Csángó-Hungarian is still the majority language, such as in Luizi-Călugăra (Lujzikalagor), Lespezi (Lészped) and Gârlenii de Sus (Rácsila), a relatively high percentage of the children are Romanian monolingual, in contrast to the situation of 1996, where almost all the children who belonged to Hungarian-speaking families spoke Csángó-Hungarian. This situation mostly fits grade 2 'severely endangered' in this factor. It is also true that as local exception to this rule, in some villages, Csángó-Hungarian enjoys better health, reaching grade 3 'definitively endangered' and even 4 simply 'unsafe'.

Factor 2: Absolute number of speakers. The question of how many Csángós can effectively speak Csángó-Hungarian or any other version of the language cannot be determined with absolute precision due to several factors. These are their self-identification as simply Hungarian, Romanian, or Catholic, their real competence in Hungarian and their acculturation of their capacity to speak Hungarian in order to avoid discrimination from Romanian speakers or even by standard-Hungarian speakers (Sándor 2005: 166, 174). There are, however, some details which may lead to approximate figures. Tánczos (2010: 145) suggests that there are almost 50,000 people who speak Hungarian as their first or their second language in Moldavia. Moreover there would be another group of about 15,000 people with passive knowledge of the language (See Table 3).

\begin{tabular}{|l|l|l|l|l|l|}
\hline $\begin{array}{l}\text { Moldavian } \\
\text { Catholics }\end{array}$ & $\begin{array}{l}\text { Hungarian } \\
\text { speakers (L1 } \\
\text { and L2) }\end{array}$ & $\begin{array}{l}\text { Native } \\
\text { Hungarian } \\
\text { speakers (L1) }\end{array}$ & $\begin{array}{l}\text { Second } \\
\text { language } \\
\text { Hungarian } \\
\text { speakers (L2) }\end{array}$ & $\begin{array}{l}\text { Passive } \\
\text { knowledge of } \\
\text { Hungarian }\end{array}$ & $\begin{array}{l}\text { No competence } \\
\text { in Hungarian }\end{array}$ \\
\hline $\begin{array}{l}232,045 \\
(100 \%)\end{array}$ & $\begin{array}{l}48,752 \\
(21 \%)\end{array}$ & $\begin{array}{l}26,040 \\
(11 \%)\end{array}$ & $\begin{array}{l}22,712 \\
(10 \%)\end{array}$ & $\begin{array}{l}15,008 \\
(6 \%)\end{array}$ & $\begin{array}{l}168,285 \\
(73 \%)\end{array}$ \\
\hline
\end{tabular}

Table 3. Hungarian among the Catholics of Moldavia (Tánczos, 2010: 145)

Factor 3: Proportion of speakers within the total population. Klára Sándor (2005: 171) estimates the percentage of Hungarian-speaking Catholics (Csángós) in twenty percent of the total Catholic population of the region of Moldavia. Attila Hegyeli (2009) is slightly more optimistic and considers that about twenty-five percent of the Moldovan Catholics are Hungarian-speakers. Those details are not far from the ones provided by Tánczos (2010 and 2012), who estimates that about eleven percent of the Moldavian Catholics are native Hungarian speakers, another ten percent are able to use the language (although they are Romanian native speakers), and still another six percent have a passive knowledge of Hungarian. The rest of the population, which comprises about seventy-three percent, consist of mostly Romanian monolinguals (see Table 3). The Hungarian speakers are, therefore, a substantial minority among the Moldovan Catholics/Csángós which puts the language in a position of severely endangered (or degree 2) in the UNESCO's Language Vitality and Endangerment framework. 
Ferdinand, Siarl. "Situation of the Csángó Dialect of Moldavia in Romania." Hungarian Cultural Studies. e-Journal of the American Hungarian Educators Association, Volume 9 (2016): http://ahea.pitt.edu DOI:

Factor 4: Shifts in domains of language use. In many Csángó villages, the only Hungarian-speakers are people over forty-five and often over sixty, which points to an evident rupture in the chain of language transmission. The language is only used among the older people when interacting with each other. Fortunately, there are still some villages where there are young people and even children among the Csángó-Hungarian speakers, although very often the first language of these speakers is Romanian (Kontra 2012: 9). In those places where the younger generations still maintain the language, the interaction in the minority language is also common between speakers of the same age although, depending on the village, those interactions may either be more fluent or more limited. This phenomenon is caused by two main reasons, the low prestige of the local Hungarian dialect, which is absent in most important domains such as education and administration, and the limited ability of the speakers to use Csángó, since most of the members of the younger generations have Romanian as their first language (Heltai 2012: 80, $85,86)$. These facts put Csángó-Hungarian in a very difficult situation. Although it is clear that in many villages it is a language used in highly limited domains (grade 1 in the scale) or even an extinct language (grade 0), a more positive perspective would be to assign it a grade 3 , "dwindling domains" according to the LVE scale, since apparently many children are still speakers or semi-speakers, while a high percentage of parents are Romanian-Csángó bilingual.

Factor 5: Response to new domains and media. Csángó is a dialect of a medium size European language, Hungarian, which is official in the European Union and in Hungary, regionally official in Serbia and Slovenia, and it is also recognized as a minority language in several other countries. The normative language enjoys, therefore, good health in all domains. This fact makes it difficult to determine the real state of Hungarian regarding new technologies, such as the Internet or mobile telephony. Most computers, smartphones, and other devices which are sold in Romania have their menus in Hungarian. There are also thousands of websites available in Hungarian; however, it can be said that most of those products come from Hungary and Transylvania. The number of local websites created by Csángós in the Csángó dialect or even in standard Hungarian is very limited. Traditional media in Csángó is also very limited. Although there is a radio station called Csángó Rádió which broadcasts from 6 am till about midnight on a daily basis, there is no local newspaper or magazine written in the dialect. Almost all printed material is produced in Transylvania or in Hungary where the standard Hungarian form is used. On this point, it must be admitted that the production of materials in dialects is not generalized in most countries. However, it is common for some European dialects with a strong personality such as Swiss German (Schwyzertütsch), Swabian (Swäbisch) in Germany, or Western Asturian (Llionés and Mirandés) in Spain and Portugal to have at least some presence in most domains, including the Internet. Csángó is linguistically one of the most peculiar dialects of Europe but its presence in new technologies and media cannot be compared to that of the dialects mentioned. Therefore, although standard Hungarian is a very active language in technology and media, the situation in Moldavia is totally different and the level of use of Csángó-Hungarian in new technologies and media is only minimal or grade 1 according to LVE.

Factor 6: Availability of materials for language education and literacy. The traditional lack of education in Csángó-Hungarian provokes a lack of need for materials produced in the dialect. In fact, all the material used at school is written in standard Hungarian since besides some descriptions of the dialect written for linguistic purposes, there is almost nothing published in Csángó. The grade that Csángó achieves in this factor is 2, since there are some materials written in the dialect which may have some symbolic significance for some members of the 
Ferdinand, Siarl. "Situation of the Csángó Dialect of Moldavia in Romania." Hungarian Cultural Studies. e-Journal of the American Hungarian Educators Association, Volume 9 (2016): http://ahea.pitt.edu DOI:

community, but they would be useless for the rest of the population. Literacy education in Csángó is not a part of the national (Romanian) school curriculum.

Factor 7: Governmental and Institutional Language Attitudes and Policies, Including Official Status and Use. According to Article 13 of the current Romanian constitution, "In Romania, the official language is Romanian." None of the articles of this Law makes reference to any other language or languages spoken by the native minorities of Romania. Hungarian, therefore, is not an official language in Romania and as long as the 1991 Constitution remains in force, it will never be since Article 148 (1) states that the issue of official language shall not be subject to revision. Although there are some attempts to make Hungarian official in the areas where it is a majority language, such as the counties of Covasna (Kovászna) and Harghita (Hargita), they have always found opposition from the Romanian central government and from influential sectors of the Romanian society. The opposition is based fear that such recognition would destroy the unity of Romania and lead to a refusal of the minorities to integrate into Romania (Ungheanu 2009: 5, 6). Although Romania signed the European Charter for Regional or Minority Languages in 2007 which allowed national minority languages to obtain some fundamental rights, those rights only apply to communities where the ethnic group constitutes more than twenty percent of the local population. Moreover, the rights granted by the Romanian administration are very limited, as proven by the fact that communities are not allowed to use or adopt place-names in a minority language, or that the minority language cannot be used in local or county council meetings unless at least one third of the councilors belong to that minority, or that councilors can only use their minority language if at least one fifth of them belong to that minority.

All these measures have been criticized by the Council of Europe for being unfair and going against the spirit of the Charter (Council of Europe 2012: 7). Therefore, Csángó is not official in any of the villages inhabited by the minority. As for education, the current Romanian constitution states in its Article 32 (2) that "Education of all grades shall be in Romanian." Nevertheless, the next section of the same article, 32 (3), also declares that "The right of persons belonging to national minorities to learn their mother tongue, and their right to be educated in this language are guaranteed; the ways to exercise these rights shall be regulated by law." Although there are no schools offering programs through the medium of Csángó-Hungarian or Standard-Hungarian in Bacău (Bákó) County, there are about twenty-two centers where Hungarian is taught mainly in extracurricular lessons by volunteer teachers from Transylvania and Hungary, since the Romanian government does not prepare local teachers to teach in their dialect (Szucher 2010). In 2010, there were 1600 children learning the Hungarian language, however there is no education of other subjects through the medium of Hungarian in Moldavia. Its situation would fit Grade 2 (active assimilation) of Factor 7 in UNESCO's LVE. This grade implies that the government, in this case the Romanian government, encourages the members of the Csángó community to abandon their language by providing education only in Romanian. Speaking and/or writing in non-dominant languages is not encouraged.

Factor 8: Community Members' Attitudes towards Their Own Language. The CsángóHungarian dialect does not enjoy much prestige. It is often despised by both, Romanian speakers and by the rest of Hungarian speakers of Romania, who often consider Csángó an unpleasant and improper way of speaking Hungarian. While in Hungary, Csángó is traditionally considered a beautiful ancient form of Hungarian, it is nevertheless only tolerated to a certain extent since, in real life, speakers are supposed to use the normative form (Sándor 2005: 174). Csángó-speakers do not hold their dialect in high regard either and it is often associated with local low-prestige 
Ferdinand, Siarl. "Situation of the Csángó Dialect of Moldavia in Romania.” Hungarian Cultural Studies. e-Journal of the American Hungarian Educators Association, Volume 9 (2016): http://ahea.pitt.edu DOI:

activities (see Table 4). In fact, although old people refer to it simply as "Hungarian," the younger generations differentiate between the local low-prestige dialect, which they often call "Csángó," and the standard Hungarian spoken by the Szeklers, which they call "pure Hungarian," a prestigious language (Heltai 2012: 74). Csángó would be in grade 2 in the LVE scale since it is only supported by some members of the community, while most people are indifferent or support language shift to Romanian.

\begin{tabular}{|l|l|l|}
\hline & \multicolumn{1}{|c|}{ Romanian } & \multicolumn{1}{|c|}{ Hungarian } \\
\hline 1. lifestyle & modern & traditional \\
\hline 2. environment & wider society & local society \\
\hline 3. local language setting & school & community \\
\hline 4. ways of acquisition & conscious, planned & spontaneous \\
\hline 5. model speakers & caregivers (parents) & adult speakers \\
\hline 6. activity & learning & farming \\
\hline 7. speaker's age & child & adult \\
\hline
\end{tabular}

Table 4. Values linked to the Romanian and the Hungarian languages in Moldavia (in Bodó 2012, 40)

Factor 9: Type and Quality of Documentation. Documentation in the Csángó dialect is very scarce. There are no more than some dialect wordlists and a few collections of legends and old ballads. The material used for teaching the language, when there is that possibility, is almost exclusively written in normative Hungarian, mainly imported from Hungary or from Transylvania. There are, however, some recordings and audiovisual material in the dialect, a percentage of it available as online videos, TV shows, and other formats, and some material collected by researchers (Heltai 2012: 72). Although that material may be useful to linguists and other researchers, it is doubtful that it may have the same effect within the Csángó community, which is mainly composed of peasants. There is, thus, an urgent necessity to create and collect more material in the dialect since its situation must be considered fragmentary (Grade 2).

After analyzing all the factors proposed by UNESCO (2003), there is strong evidence that Csángó is experiencing a critical situation and, thus, that it must be considered to be part of the severely endangered languages of Europe, along with others like Breton or Occitan (see Table 5). The language is not regularly used at school, in religious services, or in the local government. In fact, both, the Catholic Church and the Romanian government are working with more or less the same transparency and intensity to culminate a linguistic assimilation of the Csángós with their Romanian-speaking neighbors. The impossibility of using the language in many domains due to its role as a minority language, spoken by about twenty percent of the total Csángó community that is also a minority in Moldavia, and the lack of prestige provoked by religious and political pressures has also created an inferiority complex within the Hungarian speakers, 
Ferdinand, Siarl. "Situation of the Csángó Dialect of Moldavia in Romania." Hungarian Cultural Studies. e-Journal of the American Hungarian Educators Association, Volume 9 (2016): http://ahea.pitt.edu DOI:

10.5195/ahea.2016.231

who have ceased to teach their language to their children. Although in some villages all generations can speak the language, in general, most of the Csángó speakers are aged over sixty.

\begin{tabular}{|c|c|c|}
\hline Factor & Csángó & Explanation \\
\hline $\begin{array}{l}\text { Factor 1- Intergenerational } \\
\text { Language Transmission }\end{array}$ & $\begin{array}{l}\text { 2; severely } \\
\text { endangered }\end{array}$ & $\begin{array}{l}\text { The language is used mostly by the grandparental } \\
\text { generation and up. }\end{array}$ \\
\hline $\begin{array}{l}\text { Factor } 2 \text { - Absolute Number of } \\
\text { Speakers }\end{array}$ & 49,000 & \\
\hline $\begin{array}{l}\text { Factor } 3 \text { - Proportion of } \\
\text { Speakers within the Total } \\
\text { Population }\end{array}$ & $\begin{array}{l}\text { 2; severely } \\
\text { endangered }\end{array}$ & A minority speak the language ( $11 \% \mathrm{~L} 1 ; 10 \% \mathrm{~L} 2)$. \\
\hline $\begin{array}{l}\text { Factor } 4 \text { - Shifts in Domains of } \\
\text { Language Use }\end{array}$ & $\begin{array}{l}\text { 3; dwindling } \\
\text { domains }\end{array}$ & $\begin{array}{l}\text { The language is used in home domains and for } \\
\text { many functions, but the dominant language begins } \\
\text { to penetrate even home domains. }\end{array}$ \\
\hline $\begin{array}{l}\text { Factor } 5 \text { - Response to New } \\
\text { Domains and Media }\end{array}$ & 1 ; minimal & The language is used only in a few new domains. \\
\hline $\begin{array}{l}\text { Factor } 6 \text { - Availability of } \\
\text { Materials for Language } \\
\text { Education and Literacy }\end{array}$ & 2 & $\begin{array}{l}\text { Written materials exist, but they may only be useful } \\
\text { for some members of the community; for others, } \\
\text { they may have a symbolic significance. Literacy } \\
\text { education in the language is not a part of the school } \\
\text { curriculum. }\end{array}$ \\
\hline $\begin{array}{l}\text { Factor } 7 \text { - Governmental and } \\
\text { Institutional Language } \\
\text { Attitudes and Policies } \\
\text { Including Official Status and } \\
\text { Use }\end{array}$ & $\begin{array}{l}\text { 2; active } \\
\text { assimilation }\end{array}$ & $\begin{array}{l}\text { Government encourages assimilation to the } \\
\text { dominant language. There is no protection for } \\
\text { minority languages. }\end{array}$ \\
\hline $\begin{array}{l}\text { Factor } 8 \text { - Community } \\
\text { Members' Attitudes towards } \\
\text { Their Own Language }\end{array}$ & 2 & $\begin{array}{l}\text { Some members support language maintenance; } \\
\text { others are indifferent or may even support } \\
\text { language loss. }\end{array}$ \\
\hline $\begin{array}{l}\text { Factor } 9 \text { - Type and Quality of } \\
\text { Documentation }\end{array}$ & $\begin{array}{l}2 ; \\
\text { fragmentary }\end{array}$ & $\begin{array}{l}\text { There are some grammatical sketches, wordlists, } \\
\text { and texts useful for limited linguistic research but } \\
\text { with inadequate coverage. Audio and video } \\
\text { recordings of varying quality, with or without any } \\
\text { annotation, may exist. }\end{array}$ \\
\hline
\end{tabular}

Table 5. State of the Csángó Hungarian dialect in Moldavia according to UNESCO's LVE 
Ferdinand, Siarl. "Situation of the Csángó Dialect of Moldavia in Romania." Hungarian Cultural Studies. e-Journal of the American Hungarian Educators Association, Volume 9 (2016): http://ahea.pitt.edu DOI:

10.5195/ahea.2016.231

\section{Conclusions: Csángó Revival}

The revival of a language can only be achieved by creating a sense of dignity and usefulness within the community, both of which Csángó unfortunately lacks. Therefore, the only possibility for the dialect to survive is to enhance both variables. Official recognition and real support from the main institutions would be an invaluable help to attain these objectives. However, the circumstances in Romania do not seem to be favorable for most language minorities, especially those who are even denied their minority status. Nevertheless, this negative situation can be overcome by implementing some local-based strategies.

Enhancing usefulness. Csángó is still alive and it is spoken by tens of thousands of individuals in a relatively small area, and therefore there is no need to reconstruct it from testimonies of old speakers or ancient documents, as has been the case, for example, in some other languages, such as Cornish or several Australian languages, attempting a revival. Moreover, it is a dialect of an official language of Europe, Hungarian, which is spoken by about fourteen million people, a high percentage of them being monolingual. This privileged situation may help Csángó to be able to recover at least some of the lost domains. The goal of the language must be to transcend itself by, for example, involving youth groups, young people's associations and parents' groups where the language is used or encouraged (Fishman 1991: 91). These initiatives must be led as much as possible by locals, due to the differences and often mutual incomprehension between Csángós and the rest of Hungarian-speaking groups (Sándor 2000: 151). Local teachers and language leaders, on their part, must be active in their support of Csángó as well as the rest of the community. They must be kept talking and supporting it in any way possible. Otherwise, all the efforts would lose their impetus and the vitality of the language would continue its decline (Jones 1998: 348).

Enhancing language dignity. A useful language can always retain its dignity in at least some domains. Enhancing the usefulness of a threatened language implies enhancing the interest in learning it. However, if nothing else is done, Csángó would continue to be a fragmented local speech, valid only in each village. Due to the rejection of using normative Hungarian, Sándor (2000: 161) proposes the creation of a common Csángó-Hungarian for all the community. This normative approach would help Csángó discard its stigma as a corrupt dialect, a mixture of "pure" Hungarian and Romanian (Sándor 2000: 151). Both the new koine and the traditional dialects could be also employed in activities and events such as song concerts, theatrical performances, poetry readings, lectures, publications, and the awarding of prizes which could eventually lead to the public visibility of Csángó-Hungarian which would have a vital feedback influence on the community of interest. All these initiatives could, in turn, create the feeling that the local dialect may be local, but a worthy tool for general communication which is also a heritage for the community (Fishman 1991: 91).

\section{Works Cited}

Andreescu, Gabriel. 2004. "Cultural and Territorial Autonomy and the Issue of Hungarian Identity,” Hungarian Studies 21.1-2: 61-84.

Asociaţia Romano-Catolicilor Dumitru Mărtinaş. 2014. "Cine sunt ceangăii?” ['Who Are the Csángós'] AsroCatolic. http://www.asrocatolic.ro/despre.html

Baker, Robin. 1997. “On the Origin of the Moldavian Csángós.” The Slavonic and East European Review 75.4: 658-680. 
Ferdinand, Siarl. "Situation of the Csángó Dialect of Moldavia in Romania." Hungarian Cultural Studies. e-Journal of the American Hungarian Educators Association, Volume 9 (2016): http://ahea.pitt.edu DOI:

10.5195/ahea.2016.231

Benö, Attila. 2012. "The Most Important Areas and Results of the Research on Hungarian Language in Moldavia." In Language Use, Attitudes, Strategies: Linguistic Identity and Ethnicity in the Moldavian Csángó Villages. Eds. Lehel Peti and Vilmos Tánczos. Cluj-Napoca: The Romanian Institute for Research on National Minorities: 1330.

Bitay, Árpád. 1926. “A Moldvai magyarság” ['The Hungarians of Moldavia']. Erdélyi Tudományos Füzetek 4: 3-24.

Bodó, Csanád. 2012. "Language Socialisation Practices in Moldavian Bilingual Speech Communities." In Language Use, Attitudes, Strategies: Linguistic Identity and Ethnicity in the Moldavian Csángó Villages. Eds. Lehel Peti and Vilmos Tánczos. ClujNapoca: The Romanian Institute for Research on National Minorities: 31-49.

Brassai, Imre. 1913. A Romániai Csángók Szomorú Sorsa ['The Sad Destiny of the Romanian Csángós']. Gyergószentmiklós: Sándory Mihaly.

Campbell, Lyle R. 1994. "Language Death.” The Encyclopedia of Language and Linguistics. 1960-1968. Ed. Ron E. Asher. Oxford: Pergamon Press.

Council of Europe. 2001. The Csángó Minority Culture in Moldavia. Strasbourg: Council of Europe.

Council of Europe. 2012. European Charter for Regional or Minority Languages. Application of the Charter in Romania. Strasbourg: Council of Europe.

Crystal, David. 2000. Language Death. Cambridge: Cambridge UP.

Diószegi, László, ed. 2002. Hungarian Csángós in Moldavia. Budapest: Teleki László Foundation.

Fenyvesi, Anna, ed. 2005. Hungarian Language Contact Outside Hungary. Amsterdam: John Benjamins.

Filip, Olimpia. 2011. "Ceangaii, comunitatea fara trecut si present” ['Csangos, a Community without Past and Present']. Adevarul. 23 May. http://adevarul.ro/news/societate/ceangaii-comunitatea-trecut-prezent1_50acc8497c42d5a66389ce0e/index.html

Fishman, Joshua A. 1991. Reversing Language Shift. Theoretical and Empirical Foundations of Assistance to Threatened Languages. Clevedon: Multilingual Matters.

Harrison, K. David. 2007. When Languages Die. Oxford: Oxford UP.

Hegyeli, Attila. 2009. “Tíz éves a Moldvai Csángó Oktatási Program. Rövid bemutató" ['Ten Years of the Moldavian Csángó Education Program: Short Presentation']. Csango.org. http://www.csango.ro/index.php?page=oktatas

Heltai, János I. 2012. "Language Shift in Moldavia." In Language Use, Attitudes, Strategies: Linguistic Identity and Ethnicity in the Moldavian Csángó Villages. Eds. Lehel Peti and Vilmos Tánczos. Cluj-Napoca: The Romanian Institute for Research on National Minorities: 71-96.

Institutul Național de Statistică. 2012. Recensământul populaţiei şi al locuinţelor 2011 ['Population and Housing Census 2011']. http://www.constanta.insse.ro/phpfiles/sR_TAB_8.pdf

Jones, Mary C. 1998. Language Obsolescence and Revitalization. Oxford: Clarendon Press.

Kálmán, Benda. 2002. “The Hungarians of Moldavia (Csángós) in the $16^{\text {th }}-17^{\text {th }}$ Centuries.” In Hungarian Csángós in Moldavia. Ed. László Diószegi. Budapest: Teleki László Foundation: 7-50. 
Ferdinand, Siarl. "Situation of the Csángó Dialect of Moldavia in Romania." Hungarian Cultural Studies. e-Journal of the American Hungarian Educators Association, Volume 9 (2016): http://ahea.pitt.edu DOI:

Kiss, Jenő. 2012. "On the Hungarian Language Use of the Moldavian Csángós.” In Language Use, Attitudes, Strategies: Linguistic Identity and Ethnicity in the Moldavian Csángó Villages. Eds. Lehel Peti and Vilmos Tánczos. Cluj-Napoca: The Romanian Institute for Research on National Minorities: 111-120.

Kontra, Miklós 2012. "Prefatory Note to the Csángó Issues." In Language Use, Attitudes, Strategies: Linguistic Identity and Ethnicity in the Moldavian Csángó Villages. Eds. Lehel Peti and Vilmos Tánczos (Cluj-Napoca: The Romanian Institute for Research on National Minorities: 9-12.

László, Gyula. 1986. Árpád Népe ['Árpád's People’]. Budapest: Helikon.

Năstase, Adrian. 2002. Răspuns la interpelarea formulată de dumnul deputat Adrian Moisoiu Grupul parlamentar al PRM, privind poziţia premierului şi a Guvernului faţă de pierderea autorităţii statului în judeţele Harghita şi Covasna şi problema ceangăilor din Moldova ['Response to the Interpellation by Mr Adrian Moisoiu MP of the PRM Parliamentary Group on the Position of the Prime Minister and the Government Toward the Loss of Authority of the Counties of Harghita and Covasna and the Problem of the Csangos in Moldavia']. Bucharest: Government of Romania.

Peti, Lehel and Vilmos Tánczos. 2012, Language Use, Attitudes, Strategies: Linguistic Identity and Ethnicity in the Moldavian Csángó Villages. Cluj-Napoca: The Romanian Institute for Research on National Minorities.

Râmneanţu, Petru. 1944. Die abstammung der Tschangos ['The Lineage of the Csangos']. Sibiu.

Sándor, Klára. 2000. "National Feeling or Responsibility. The Case of the Csángó Language Revitalization." Multilingua 19.1-2: 141-168.

Sándor, Klára. 2005. "The Csángós of Romania." Hungarian Language Contact Outside Hungary. Ed. Anna Fenyvesi. Amsterdam: John Benjamins: 163-185.

Shetreet, Shimon. 2007. "The Model of State and Church Relations and Its Impact on the Protection of Freedom of Conscience and Religion: A Comparative Analysis and a Case Study of Israel." In Religion in the Public Sphere: A Comparative Analysis of German, Israeli, American and International Law. Eds. Winifred Brugger and Michael Karayanni. Berlin: Springer: 87-161.

Stir, Victor. 2011. Limba şi etnia la recensământ ['Language and Ethnicity in the Census']. Mesagerul, 3 October. http://www.mesagerul.ro/2011/10/03/limba-si-etnia-larecensamant

Szucher, Ervin. 2010. "Tíz éve müködik szervezett formában magyar nyelvü oktatás a Csángóföldön" [ 'Ten Years of Organized Education through the Medium of Hungarian in Csángóland']. Krónika, 10 May. http://www.kronika.ro/erdelyihirek/tiz_eve_mukodik_szervezett_formaban_magyar_nyelvu_oktatas_a_csangofoldon

Tánczos, Vilmos. 1997. "Hungarians in Moldavia." Magyar Kisebbség 1-2. 7-8: 370-390.

Tánczos, Vilmos. 2002. “About the Demography of the Moldavian Csángós.” In Hungarian Csángós in Moldavia. Ed. László Diószegi. Budapest: Teleki László Foundation: 117-148.

Tánczos, Vilmos. 2010. "A moldvai csángók magyar nyelvismerete 2008-2010-ben" ['Language Competence of the Moldavian Csángós']. Magyar Kisebbség, 57-58: 62-156. 
Ferdinand, Siarl. "Situation of the Csángó Dialect of Moldavia in Romania." Hungarian Cultural Studies. e-Journal of the American Hungarian Educators Association, Volume 9 (2016): http://ahea.pitt.edu DOI:

Tánczos, Vilmos. 2012. "Estimated Hungarian Language Command Among the Moldavian Csángós, 2008-2010." Language Use, Attitudes, Strategies. Linguistic Identity and Ethnicity in the Moldavian Csángó Villages. Eds. Lehel Peti and Vilmos Tánczos. Cluj-Napoca: The Romanian Institute for Research on National Minorities: 239278.

Uehling, Greeta L. 2004. Beyond Memory: The Crimean Tatars' Deportation and Return. New York: Palgrave Macmillan.

UNESCO. 2003. Language Vitality and Endangerment. Paris: UNESCO. http://www.unesco.org/new/fileadmin/MULTIMEDIA/HQ/CLT/pdf/Language_vitality_ and_end_endangerment_EN.pdf

Ungheanu, Mihail. 2009. Situaţia juridică a drepturilor minorităţii maghiare în România ['Juridical Situation of the Hungarian Minorities in Romania']. Academia Română: Centrul European pentru Studii în Probleme Etnice.

Vincze, Gábor. 2002. "An Overview of the Modern History of the Moldavian CsángóHungarians.”'In Hungarian Csángós in Moldavia. Ed. László Diószegi. Budapest: Teleki László Foundation: 51-82. 